\title{
POLYAMINES IN BOVINE EPIDIDYMAL SPERMATOZOA
}

\author{
E. BAMBERG, M. WEISER AND H. DESSER \\ Institut für Biochemie, Institut für Medizinische Chemie, \\ Tierärztliche Hochschule, Ludwig Boltzmann-Institut für Veterinärmedizinische \\ Endokrinologie und für Leukämieforschung und Hämatologie, Wien, Austria
}

(Received 26th February 1975)

The stimulation of biosynthesis of putrescine and the polyamines spermidine and spermine has been observed in many processes of cell proliferation and differentiation in eukaryotic organisms (Tabor \& Tabor, 1964; WilliamsAshman \& Reddi, 1971; Cohen, 1971 ; Williams-Ashman et al., 1972; Bachrach, 1973), although the functional significance of these observations is still unclear and has evoked much discussion (Bachrach, 1973; Russell, 1973). The enhancement of putrescine and polyamine production has been correlated with protein-, RNA- and DNA-synthesis (Russell, 1973), and these diamines are probably involved in the regulation of mitosis (Fillingame \& Morris, 1973). Since an influence of polyamines on membrane functions has been shown (Tabor \& Tabor, 1964; Lockwood \& East, 1974), we have investigated the alterations of the polyamine content of epididymal spermatozoa during their maturation in the epididymis.

The epididymis of mammals is involved in two functions, namely that of maturation and storage of spermatozoa (Mann, 1964; Orgebin-Crist, 1969; Glover \& Nicander, 1971). A great many biochemical processes have been examined in maturing spermatozoa, but have not included the metabolism of biologically active polyamines. The present study involved analysis of the content of putrescine, spermidine, spermine and histamine in spermatozoa taken from distinct regions of the bovine epididymis. In addition, the activity of ornithine decarboxylase (EG 4.1.1.17) and diamino oxidase (EC 1.4.3.6), two enzymes associated with polyamine metabolism, was studied in these spermatozoa.

Immediately after slaughter the epididymides of six bulls were cooled on ice and transported to the laboratory within $30 \mathrm{~min}$. Each epididymis was divided into four segments: the cauda (Segment 4), the corpus (Segment 3) and the two parts of the caput epididymidis on either side of the flexure (Segments 2 (distal) and 1 (proximal)). These portions were then cut open with a razor blade and the spermatozoa from two epididymides removed by washing with Ringer's solution (Mann, 1964). The suspensions of spermatozoa thus obtained were centrifuged at $380 \mathrm{~g}$ at room temperature and the pellet resuspended in $5 \mathrm{ml}$ Ringer's solution. Cell counts were performed on these suspensions. Microscopic examination of stained smears from the sperm suspensions showed no contamination with epithelial cells. 
For the analysis of the polyamines the sperm suspensions were again sedimented by centrifugation, this time at $1300 \mathrm{~g}$, and the pellet extracted with 5 $\mathrm{ml}$ of a $3 \%$ sulphosalicylic acid solution in $0.05 \mathrm{~N}-\mathrm{HCl}$. After homogenization at $0^{\circ} \mathrm{C}$ by ultrasonic treatment $(28$ times for $15 \mathrm{sec}$ ) the material was stored at $-20^{\circ} \mathrm{C}$ for $16 \mathrm{hr}$. After thawing it was then centrifuged at $1500 \mathrm{~g}$ for $2 \mathrm{~min}$ and the polyamines determined in the supernatants according to the method of Marton et al. (1973) using column chromatography and an adapted automatic amino acid analyser.

For the estimation of enzymatic activity the extracts obtained from suspensions of spermatozoa after homogenization and centrifugation at $120,000 \mathrm{~g}$ were incubated with the proper substrates as follows: ornithine decarboxylase was determined by the method of Jones et al. (1972) using an incubation medium containing $0.75 \mathrm{~mm}$-sodium potassium phosphate buffer, $\mathrm{pH} 6.8$, 2 mm-EDTA, 0.5 mm-pyridoxalphosphate, and $5 \mathrm{~mm}$-dithiothreitol. Diamino oxidase was determined by the method of Kusche et al. (1973) using 0.2 M-

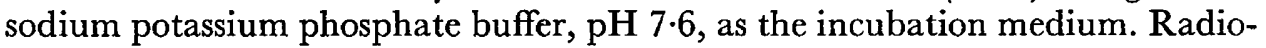
activity was measured in a liquid scintillation spectrometer (Packard).

Table 1. The amine content ( $\mathrm{nmol} / 10^{8}$ cells) of the spermatozoa from the bovine epididymis

\begin{tabular}{|c|c|c|c|c|}
\hline Amine & Segment 1 & Segment 2 & Segment 3 & Segment 4 \\
\hline $\begin{array}{l}\text { Putrescine } \\
\text { Spermidine } \\
\text { Spermine } \\
\text { Histamine }\end{array}$ & $\begin{array}{r}111 \cdot 7 \pm 72 \cdot 4(6) \\
38.4 \pm 27 \cdot 2(5) \\
58 \cdot 2 \pm 40 \cdot 8(4) \\
70 \cdot 5 \pm 63 \cdot 2(5)\end{array}$ & $\begin{array}{r}8.5 \pm 4 \cdot 2(5) \\
4.5 \pm 2 \cdot 3(5) \\
11 \cdot 2 \pm 8 \cdot 8(4) \\
1.6 \pm 1.2(3)\end{array}$ & $\begin{array}{r}7 \cdot 0 \pm 2 \cdot 1(5) \\
9 \cdot 0 \pm 4 \cdot 7(5) \\
25 \cdot 4 \pm 11 \cdot 6(3) \\
7.9 \pm 0.6(4)\end{array}$ & $\begin{array}{l}2.5 \pm 2.1 \quad(6) \\
1.2 \pm 0.6(5) \\
7.7 \pm 6.8(5) \\
1.9 \pm 0.1(2)\end{array}$ \\
\hline
\end{tabular}

Values are Means \pm S.D. with the number of determinations in parentheses.

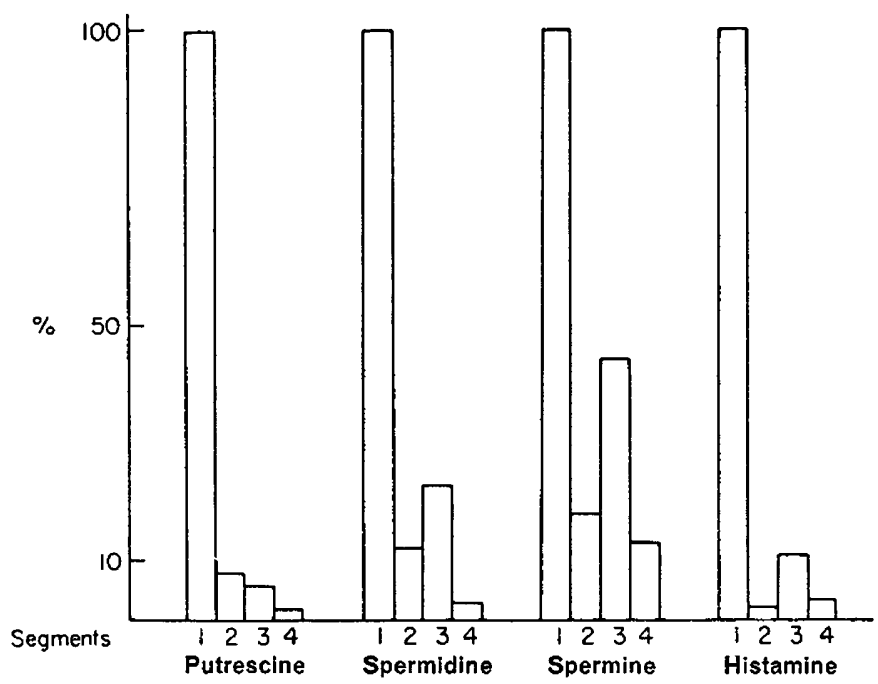

TExT-FIG. 1. The relative decrease in the amine content of bovine epididymal spermatozoa. See text for distinction of Segments. 
The results of the amine determinations are shown in Table 1. During passage of spermatozoa from the caput to the cauda epididymidis the content of putrescine, spermidine, spermine and histamine decreased markedly. The percentage change in the sperm content of the four amines between Segments 1 and 4 is shown in Text-fig. 1. In Segment 3 the content of spermidine, spermine and histamine (but not that of putrescine) was higher than in the two adjoining segments. Diamino oxidase activity was detected in extracts of spermatozoa from all four segments, but the activity recorded was consistently less than $1.4 \mathrm{mu} / \mathrm{mg}$ protein, i.e. too low to enable quantitative comparison between the four segments. Ornithine decarboxylase could not be detected in the spermatozoa.

These variations in polyamine content may influence the membranes of epididymal spermatozoa during their maturation, resulting in alterations of function. We hope to extend our observations concerning the polyamines and the two enzymes to testicular and ejaculated spermatozoa.

This paper is dedicated to Professor M. K. Zacherl on the occasion of his 70th birthday anniversary. We are grateful to Professor T. Mann and Dr G. Lutwak-Mann for valuable discussion during the preparation of the manuscript.

\section{REFERENCES}

Bachracir, U. (1973) Function of Naturally Occurring Polyamines. Academic Press, New York.

Cohen, S.S. (1971) Introduction to the Polyamines. Prentice-Hall, New Jersey.

Fillingame, R.H. \& MorRis, D.R. (1973) Polyamine accumulation during lymphocyte transformation and its relation to the synthesis, processing and accumulation of ribonucleic acid. Biochemistry, $\mathcal{N} . r$. $12,4479-4487$.

GLOVER, T.D. \& NICANDER, L. (1971) Some aspects of structure and function in mammalian epididymis. F. Reprod. Fert., Suppl, 13, 39-50.

Jones, D., Hampton, J.K., Jr \& Preslock, J.P. (1972) Ornithine decarboxylase in mouse placenta assayed by a paper-disc method for ${ }^{14} \mathrm{CO}_{2}$ capture. Analyt. Biochem. 49, 147-154.

Kusche, J., Richter, H., Hesterberg, R., Schmidt, J. \& Lorenz, W. (1973) Comparison of the $\mathrm{C}^{14}$-putrescine assay with the NADH test for the determination of diamine oxidase: description of a standard procedure with a high precision and an improved accuracy. Agents $\mathbb{E}$ Actions 3, 148156.

LockwOOD, D.H. \& EAST, L.E. (1974) Studies of the insulin-like actions of polyamines on lipid and glucose metabolism in adipose tissue cells. 7 . biol. Chem. 249, 7717-7722.

Mann, T. (1964) The Biochemistry of Semen and of the Male Reproductive Tract. Methuen, London.

Marton, L.J., VAughn, J.G., Levy, C.C. \& Russell, D.H. (1973) Elevated polyamine levels in serum and urine of cancer patients: detection by a rapid automated technique utilizing an amino acid Analyzer. In Polyamines in Normal and Neoplastic Growth, pp. 367-372. Ed. D. H. Russell. Raven Press, New York.

Orgebin-Crist, M.C. (1969) Studies on the function of the epididymis. Biol. Reprod. 1, 155-175.

RusseLL, D.H. (1973) The roles of the polyamines, putrescine, spermidine, and spermine in normal and malignant tissues. Life Sci. 13, 1635-1647.

TABOR, H. \& TABOR, C.W. (1964) Spermidine, spermine and related amines. Pharmac. Rev. 16, 245-300.

Williams-Ashman, H.G. \& Reddr, A.H. (1971) Actions of vertebrate sex hormones. A. Rev. Physiol. 33, 31-82.

Williams-Ashman, H.G., Jänne, J., Coppoc, G.L., Gerogh, M.E. \& Schenone, A. (1972) New aspects of polyamine biosynthesis in eukaryotic organisms. Adv. Enzyme Regulation 10, 225-245. 